Open Access

\title{
Application of Monoclonal and Polyclonal Antibodies to Hb Bart's for the Detection of $\alpha$ Thalassemias
}

\author{
Luksana Makonkawkeyoon $^{1, *}$, Somphon Pharephan ${ }^{1}$, Wirote Tuntiwechapikul ${ }^{1}$ and \\ Sanit Makonkawkeyoon ${ }^{2}$
}

\author{
${ }^{1}$ Department of Biochemistry, Faculty of Medicine, Chiang Mai University, Chiang Mai 50200, and ${ }^{2}$ Graduate Program \\ in Biomedical Sciences, Faculty of Allied Health Sciences, Thammasat University, Pathumthani 12121, Thailand
}

\begin{abstract}
Using a mouse monoclonal antibody (mAb) ("2D4") with high specific reactivity to Hb Bart's and a rabbit polyclonal antibody ("RPB") with high reactivity to Hb Bart's but low reactivity to HbF, an ELISA assay was developed for the quantification of $\mathrm{Hb}$ Bart's in hemolysates of peripheral blood. In the preliminary study, hemoglobin solutions containing $4,000 \mu \mathrm{g} / \mathrm{mL}$ of hemoglobin were analyzed for the concentration of $\mathrm{Hb}$ Bart's in samples collected from the following children and adult subjects of $\mathrm{HbH}$ families: 12 children with deletional $\mathrm{HbH}$ disease $\left(--/-\alpha^{3.7}\right)$ or nondeletional $\mathrm{HbH}$ disease $(\mathrm{HbH}$ disease with $\mathrm{HbCS})\left(--/ \alpha^{\mathrm{cs}} \alpha\right), 12$ adults with $\alpha^{0}$ thalassemia $(--/ \alpha \alpha), 12$ adults with deletional or nondeletional $\alpha^{+}$thalassemia $\left(-\alpha^{3.7} / \alpha \alpha\right.$ or $\left.\alpha \alpha / \alpha^{\mathrm{cs}} \alpha\right)$ and 12 normal adult subjects $(\alpha \alpha / \alpha \alpha)$. The mean \pm S.D. of Hb Bart's concentration in those with deletional $\mathrm{HbH}$ disease or $\mathrm{HbH}$ disease with $\mathrm{HbCS}, \alpha^{0}$ thalassemia, deletional or nondeletional $\alpha^{+}$thalassemia, and normal subjects were 1,374 \pm 210 (range 1,164-1,584), 1,118 \pm 357 (range 761-1,475), 451 \pm 230 (range 221-681), and $0 \mathrm{ng} / \mathrm{mL}$, respectively. When the developed ELISA was further evaluated with additional samples of various types of $\alpha$ thalassemia, including: 18 with deletional $\mathrm{HbH}$ disease $\left(--/-\alpha^{3.7}\right) ; 21$ of nondeletional $\mathrm{HbH}$ disease (HbH disease with $\mathrm{HbCS})\left(--/ \alpha^{\mathrm{cs}} \alpha\right) ; 33$ with $\alpha^{0}$ thalassemia $(--/ \alpha \alpha) ; 19$ with nondeletional $\alpha^{+}$thalassemia $\left(\alpha \alpha / \alpha^{\mathrm{cs}} \alpha\right) ; 11$ with deletional $\alpha^{+}$thalassemia $\left(-\alpha^{3.7} / \alpha \alpha\right)$ and 58 normal subjects $(\alpha \alpha / \alpha \alpha)$. It was found that the levels of Hb Bart's in deletional $\alpha^{+}$thalassemia was significantly lower than in $\alpha^{0}$ thalassemia $(p<0.001)$. The levels of $\mathrm{Hb}$ Bart's in $\alpha^{0}$ thalassemia was also significantly lower than in nondeletional and deletional $\mathrm{HbH}$ diseases $(\mathrm{p}=0.023$ and $\mathrm{p}<0.001$, respectively). When all types of $\alpha$ thalassemia were compared with normal subjects, the Hb Bart's levels in all types of $\alpha$ thalassemia were significantly higher $(\mathrm{p}<0.0001)$. All of our results indicated that the developed ELISA was highly sensitive and specific for quantitative determination of Hb Bart's in hemolysates. The ELISA assay might be used as a rapid screening test for the detection of $\alpha$ thalassemias in general population.
\end{abstract}

\section{INTRODUCTION}

Alpha thalassemias are genetic defects characterized by partial or complete suppression of $\alpha$-globin chain synthesis. The great majority of $\alpha$ thalassemias arise from the deletion of one or both of the $\alpha$-globin genes [1]. This markedly contrasts the $\beta$ thalassemias in which defects other than deletion predominate [2]. It has been found that $\alpha^{+}$ thalassemia commonly occurs across tropical Africa, the Middle East, certain regions of India, and throughout Southeast Asia [3]. However, $\alpha^{0}$ thalassemia is limited to the Mediterranean and parts of Southeast Asia, particularly southern China, Thailand, and Vietnam [1]. Due to the large number of $\alpha$ thalassemia determinants, there are several hundred different interactions that can take place. These interactions phenotypically result in one of three broad categories: (1) $\alpha$ thalassemia traits, including $\alpha^{+}$thalassemia and $\alpha^{0}$ thalassemia, in which there are mild hematological changes but no major clinical abnormalities, (2) $\mathrm{HbH}$ disease, and (3) Hb Bart's hydrops fetalis syndrome [3].

*Address correspondence to this author at the Department of Biochemistry, Faculty of Medicine, Chiang Mai University, Chiang Mai 50200, Thailand; Tel: 66-53-945323 ext. 216; Fax: 66-53-894031 or 66-53-217144;

E-mail: 1makonka@mail.med.cmu.ac.th
Infants having $\mathrm{Hb}$ Bart's hydrops fetalis syndrome typically die either in utero or soon after birth. However, $\mathrm{HbH}$ disease has an extremely variable clinical picture, ranging from asymptomatic to severe anemia requiring blood transfusions [3]. The hematological symptoms of $\mathrm{HbH}$ disease are characterized by a variable degree of anemia, hypochromic microcytic red cells, and $\mathrm{HbH}$ from $2-40 \%$. $\alpha^{0}$ Thalassemia symptoms include mild anemia and reductions in mean cell hemoglobin $(\mathrm{MCH})$ and mean cell volume $(\mathrm{MCV}), \alpha^{+}$Thalassemia symptoms are characterized by extremely mild hematological changes. The hemoglobin level and red cell indices are usually normal. Using the level of $\mathrm{Hb}$ Bart's at birth as an indicator of the presence of different $\alpha$-thalassemia alleles, low level in $1-2 \%$ range of $\mathrm{Hb}$ Bart's usually reflect the heterozygous state for $\alpha^{+}$ thalassemia. Higher levels in the $4-10 \%$ range usually indicate the heterozygous state for $\alpha^{0}$ thalassemia or the homozygous state for $\alpha^{+}$thalassemia. Higher levels, in excess of $12 \%$, suggest $\mathrm{HbH}$ disease. However, these figures only reflect as a general rule because there is a great deal of overlap in the levels of Hb Bart's at birth between different $\alpha$-thalassemia genotypes [3].

We tried to quantitative determination of $\mathrm{Hb}$ Bart's in children and adult blood of various types of $\alpha$ thalassemia by 
our developed ELISA assay. A rabbit polyclonal antibody with high reactivity to $\mathrm{Hb}$ Bart's but low reactivity to $\mathrm{HbF}$ and a mouse hybridoma producing monoclonal antibody highly specific to $\mathrm{Hb}$ Bart's were established in our laboratory [4]. An ELISA assay for the detection and quantification of Hb Bart's in hemoglobin solution using our rabbit polyclonal antibody and mouse mAb was developed [4]. Our studies demonstrated that the developed ELISA could be reliably used for the rapid screening of deletional or nondeletional $\mathrm{HbH}$ diseases, $\alpha^{0}$ thalassemia, deletional or nondeletional $\alpha^{+}$thalassemia from normal subjects.

\section{MATERIALS AND METHODOLOGY}

\subsection{Alpha Thalassemia and Normal Subjects}

Couples having an early child with $\mathrm{Hb}$ Bart's hydrops fetalis or $\mathrm{HbH}$ disease, who came with their affected child (4-14 years) to the Thalassemia Clinic at Maharaj Nakorn Chiang Mai Hospital, Chiang Mai, Thailand, were bled for 5 $\mathrm{mL}$ of blood in EDTA tubes. Normal adult volunteers both male and female were in the age of 19-30 years. Subjects of children, their parents and normal adult volunteers were studied after written informed consent. Leukocytes were isolated and DNA prepared by known salting out procedures [5]. Hemolysates were prepared from packed erythrocytes and used for the preparation of 1,000 and $4,000 \mu \mathrm{g} / \mathrm{mL}$ hemoglobin solution, $\mathrm{HbA}_{2}$ quantification and $\mathrm{Hb}$ electrophoresis for $\mathrm{Hb}$ typing. Inclusion bodies in $\mathrm{RBC}$ were determined by brilliant cresyl blue staining [6].

\subsection{Development of an ELISA for the Detection and Quantification of Hb Bart's}

\subsubsection{Rabbit Polyclonal Antibody to Hb Bart's}

Rabbit antiserum to $\mathrm{Hb}$ Bart's was generated in our laboratory by injecting New Zealand white rabbits with purified Hb Bart's using some minor modifications to known procedures [7]. The rabbit anti-Hb Bart's were purified by $\mathrm{CNBr}$-activated Sepharose 4B bound with $\mathrm{HbF}$ column (Affinity column; Pharmacia). The appropriate unbound fractions containing protein peaks with antibody activity were pooled, and the protein concentrations were determined by Bradford assay [8]. We designated the name of this rabbit polyclonal antibody to Hb Bart's as "RPB"[4].

\subsubsection{Mouse Monoclonal Antibody to Hb Bart's}

Mouse hybridomas producing mAb to Hb Bart's were prepared using some modifications to known procedures [9]. Briefly, Balb/c mice were immunized intraperitoneally with $100 \mu \mathrm{g}$ of purified Hb Bart's in complete Freund's adjuvant, and then in incomplete Freund's adjuvant. The immunized splenic cells were fused with mouse myeloma cells (X63Ag8.653). After selection with hypoxanthine, aminopterin, and thymidine (HAT) medium, a hybridoma clone was isolated and a single clone obtained by limiting dilution. This hybridoma clone, designated as "2D4"[4], was able to produce mouse $\mathrm{mAb}$ that were highly specific to $\mathrm{Hb}$ Bart's $\left(\gamma_{4}\right)$ as evaluated by exposure to $\mathrm{HbA}\left(\alpha_{2} \beta_{2}\right), \mathrm{HbA}_{2}$ $\left(\alpha_{2} \delta_{2}\right), \operatorname{HbE}\left(\alpha_{2} \beta_{2}{ }^{\mathrm{E}}\right), \mathrm{HbF}\left(\alpha_{2} \gamma_{2}\right), \mathrm{HbH}\left(\beta_{4}\right)$, and Hb Bart's $\left(\gamma_{4}\right)$ [4]. The mouse $\mathrm{mAb}$ from $2 \mathrm{D} 4$ was $\mathrm{IgG} 1$ with the $\kappa$ light chain.

\subsubsection{Detection and Quantification of $\mathrm{Hb}$ Bart's}

A sandwich ELISA, using our rabbit polyclonal antibody to Hb Bart's ("RPB") and mouse mAb specific to Hb Bart's secreting from hybridoma clone ("2D4"), was developed for the detection and quantification of $\mathrm{Hb}$ Bart's in children or adult blood hemoglobin solutions [4, 10]. After the optimal concentrations of RPB, 2D4, and goat anti-rabbit $\operatorname{IgG}$ peroxidase conjugated (Zymed) were determined for the ELISA system, an ELISA assay utilizing $10 \mathrm{ng} / \mu \mathrm{L}$ of $2 \mathrm{D} 4$ as coating antibody, $200 \mathrm{ng} / \mu \mathrm{L}$ of RPB as the secondary antibody, and a 1:1,000 ratio of goat anti-rabbit $\mathrm{IgG}$ peroxidase conjugate as the detecting reagent was employed for the detection and quantification of $\mathrm{Hb}$ Bart's in children and adult blood hemoglobin solutions.

\subsection{Hematological Investigation}

\subsubsection{Hemoglobin Typing}

The types of hemoglobin were identified by cellulose acetate (Helena tritan III membrane) electrophoresis using borate buffer at $\mathrm{pH}$ 9.0. Electrophoresis was run for 10 minutes at 160 volts and a constant current of $0.4-0.5 \mathrm{~mA} / \mathrm{cm}$. The membrane was stained with Ponceau S. Identification of migration velocities of the unknowns and known hemoglobin (standard) controls were evaluated using established methods [6]. The control hemoglobins were $\mathrm{HbA}, \mathrm{HbA}_{2}$, and $\mathrm{HbF}$.

\subsubsection{Inclusion Bodies in RBC}

EDTA blood was mixed with brilliant cresyl blue. After incubation at $37^{\circ} \mathrm{C}$, smear was made and examined by a light microscope under immersion oil [6].

\subsubsection{F-cells by Acid Elution}

Microscopic slides were smeared with thin films of whole blood, which were then allowed to dry in air. The blood smears were fixed with $80 \%$ ethyl alcohol, and then rinsed with distilled water. The air dry smears were stained with acid hematoxylin, and then counterstained with erythrosine B. The slides were examined under a microscope, red blood cells containing significant amounts of $\mathrm{HbF}$ will stain pink while red blood cells containing normal amounts (less than $2 \%$ ) of $\mathrm{HbF}$ will stain as very pale ghost cells. The degree of hemoglobin $\mathrm{F}$ gradation was as follows: $0-5$ cell/field $=$ normal, $2-9 \%=$ trace, $10-20 \%=+1$, $21-50 \%=+2,51-80 \%=+3,>80 \%=+4$, respectively [11].

\subsubsection{Percentage of $\mathrm{HbA}_{2}$}

Microcolumns made from Pasteur pipettes were filled with DEAE sephadex resin, equilibrated, and packed to a height of $7 \mathrm{~cm}$. After $20 \mathrm{~mL}$ of Tris $\mathrm{HCl}-\mathrm{KCN}$ buffer at $\mathrm{pH} 8.4(0.05 \mathrm{M})$ was passed through, $20 \mu \mathrm{L}$ of $10 \mathrm{gm} / \mathrm{L}$ hemoglobin solution was applied followed by another $20 \mathrm{~mL}$ of the same buffer wash. The same buffer at $\mathrm{pH} 8.1$ of 20 $\mathrm{mL}$ volume was passed, and the volume $\left(\mathrm{V}_{1}\right)$ was collected as hemoglobin $\mathrm{A}_{2}$. Finally, $20 \mathrm{~mL}$ of Tris-HCl-KCN buffer at $\mathrm{pH} 6.5$ was used to elute all of the remaining hemoglobin, and volume $\left(\mathrm{V}_{2}\right)$ was collected. The intensities of $\mathrm{V}_{1}$ and $\mathrm{V}_{2}$ were read at $415 \mathrm{~nm}$, and the percentage of $\mathrm{HbA}_{2}$ was calculated using the following equation [12]:

$$
\% \text { of } \mathrm{Hb} \mathrm{A}=\frac{\left(\mathrm{OD}_{1} \times \mathrm{V}_{1}\right) \times 100}{\left(\mathrm{OD}_{1} \times \mathrm{V}_{1}\right)+\left(\mathrm{OD}_{2} \times \mathrm{V}_{2}\right)}
$$




\subsection{Polymerase Chain Reaction for Genotyping of $\alpha$ Thalassemia and HbCS}

\subsubsection{Preparation of DNA and Oligonucleotide Primers}

Peripheral blood was collected using EDTA as the anticoagulant. DNA was isolated from the buffy coat of each blood sample by the salting out method as described [5].

A set of primers, 5' SEA and 3' SEA reported by Bowden et al. [13], were used to identify the $18 \mathrm{~kb}$ deletion of Southeast Asian type $\alpha$ thalassemia $\left(-{ }^{\mathrm{SEA}} / \alpha \alpha\right)$, and the expected $660 \mathrm{bp}$ amplicon was amplified from the DNA samples of patients carrying the genotype $\left(--{ }^{\mathrm{SEA}} /\right)$.

Determination of $\alpha^{+}$thalassemia, the $3.7 \mathrm{~kb}$ rightward deletion type of the $\alpha$ globin locus $\left(-\alpha^{3.7} /\right)$ was performed using the common forward primer 5-CCC TCC CCC TCG CCA AGT CCA CCC C-3 (A), which is located in the $\alpha_{2}$ promoter globin gene at position +5671 to +5695 , and the reverse primer 5'-GGG GGG AGG CCC AAG GGG CAA GAA-3 (C), which is located in the 3 UTR of the $\alpha_{1}$ globin gene at position +11254 to +11231 . In the case affected with $\alpha^{3.7} /$ determinant, the amplification of a DNA fragment of approximately $1.76 \mathrm{~kb}$ was expected. Another pair of primers $(A+B)$ that amplified the normal $\alpha_{2}$ gene consisted of the common forward primer 5-CCC TCC CCC TCG CCA AGT CCA CCC C-3 (A) and the normal reverse primer 5'-GGG AGG CCC ATC GGG CAG GAG GAA C-3' (B), which is located in the UTR of the $\alpha_{2}$ gene at position +7433 to +7409 . Because the PCR product from both pairs of primers are $1.76 \mathrm{~kb}$ for normal $\alpha_{2}$ genes and the $3.7 \mathrm{~kb}$ deletion, two separate reactions were run simultaneously for each DNA sample [14].

A similar strategy was used to detect the presence of the $4.2 \mathrm{~kb}$ leftward deletion of the $-\alpha^{4.2} /$ genotype. Two sets of primers $(\mathrm{D}+\mathrm{E}$ and $\mathrm{D}+\mathrm{F})$ reported by Baysal et al. [15] were utilized: the forward primer 5'-CCT TCC TCT CAC TTG GCC CTG AG-3 (D), which is located in exon 2 of $\varphi \alpha 1$ (2708-2730), and the reverse primer 5'-CCC TGG GTG TCC AGG AGC AAG CC 3 (E), which is located between the $\alpha_{1}$ and $\alpha_{2}$ globin genes (9023-9001). In the case of the $4.2 \mathrm{~kb}$ deletion, the DNA fragment was amplified to obtain a $2.1 \mathrm{~kb}$ amplicon. For the other pair of primers $(\mathrm{D}+\mathrm{F})$, which amplify the normal $\alpha_{2}$ gene, the forward primer (D) possesses the same sequence as above, while the normal reverse primer consists of the sequence: 5'-GGC ACA TTC CGG GAC AGA GAG AA-3 (F), which is located in $3^{\prime}$ p $\alpha 1$ gene (32893267). Amplification of a DNA fragment of approximately 581 bp was expected.

For the detection of HbCS gene, we utilized the forward primer 5-TGC GGG CCT GGG CCG CAC TGA-3, which is located at position 7224 to 7244 in the intron 2 of the $\alpha_{2}$ globin gene, and the reverse primer 5-GCC GCC CAC TCA GAC TTT ATT-3, which is located at position 7499-7479 in the untranslated region of the $\alpha_{1}$ gene as described by Makonkawkeyoon et al. [16]. Amplification of a DNA fragment of $276 \mathrm{bp}$ was expected. When the PCR product was digested with restriction enzyme, MseI or TruI (Promega), the PCR product was cut into two fragments having sizes of 164 and $112 \mathrm{bp}$ for the normal case. However, in the case of heterozygous $\operatorname{HbCS}\left(\alpha \alpha / \alpha^{\mathrm{CS}} \alpha\right)$, the
PCR product was cut into three fragments having sizes of 276, 164, and $112 \mathrm{bp}$.

\section{RESULTS}

\subsection{Hematological Findings and the Level of Hb Bart's}

Hematological studies and determination of the level of $\mathrm{Hb}$ Bart's were performed for various subjects having deletional $\mathrm{HbH}$ disease or nondeletional $\mathrm{HbH}$ disease ( $\mathrm{HbH}$ disease with $\mathrm{HbCS}), \alpha^{0}$ thalassemia, deletional or nondeletional $\alpha^{+}$thalassemia and normal subjects. Hemoglobin solution containing $4,000 \mu \mathrm{g} / \mathrm{mL} \mathrm{Hb}$ was used for quantitative determination of $\mathrm{Hb}$ Bart's. A total of 12 offspring having deletional $\mathrm{HbH}$ disease or nondeletional $\mathrm{HbH}$ disease $(\mathrm{HbH}$ disease with $\mathrm{HbCS}$ ) were preliminary evaluated; our analysis revealed a mean and standard deviation (S.D.) of Hb Bart's = 1,374 $\pm 210 \mathrm{ng} / \mathrm{mL}$ with a range from 1,164 to $1,584 \mathrm{ng} / \mathrm{mL}$ (Table 1). Hemoglobin Bart's and hematological findings in 12 fathers or mothers of $\mathrm{HbH}$ disease offspring who are $\alpha^{0}$ thalassemia revealed a mean and S.D. of Hb Bart's = 1,118 $\pm 357 \mathrm{ng} / \mathrm{mL}$ with a range from 761 to $1,475 \mathrm{ng} / \mathrm{mL}$ (Table 2). Similarly, Table 3 shows the concentrations of $\mathrm{Hb}$ Bart's and hematological findings in 12 fathers or mothers of $\mathrm{HbH}$ disease offspring who are deletional or nondeletional $\alpha^{+}$thalassemia, revealing a mean and S.D. of $\mathrm{Hb}$ Bart's $=451 \pm 230 \mathrm{ng} / \mathrm{mL}$ with a range from 221 to $681 \mathrm{ng} / \mathrm{mL}$. In contrast, we were unable to detect or quantify $\mathrm{Hb}$ Bart's in any of the 12 normal subjects.

\subsection{Further Evaluation of Hb Bart's Level in Hemoglobin Solution}

The level of $\mathrm{Hb}$ Bart's was further evaluated in more subjects of $\alpha$ thalassemia including: 18 having deletional $\mathrm{HbH}$ disease, 21 of nondeletional $\mathrm{HbH}$ disease $(\mathrm{HbH}$ disease with $\mathrm{HbCS}$ ), 33 having $\alpha^{0}$ thalassemia, 11 having deletional $\alpha^{+}$thalassemia, 19 of nondeletional $\alpha^{+}$thalassemia and 58 normal subjects. As shown in Fig. (1A), the level of $\mathrm{Hb}$ Bart's in hemoglobin solution containing $\mathrm{Hb}$ concentration of $4,000 \mu \mathrm{g} / \mathrm{mL}$ were: $1,537 \pm 339,1,268 \pm 284,967 \pm 438$, $318 \pm 221,712 \pm 420$ and $0 \mathrm{ng} / \mathrm{mL}$ in the above mentioned subjects, respectively. Fig. (1B) shows the median with $25-75 \%$ quartiles of $\mathrm{Hb}$ Bart's levels in 18 subjects of deletional $\mathrm{HbH}$ disease, 21 of $\mathrm{HbH}$ disease with $\mathrm{HbCS}, 33$ with $\alpha^{0}$ thalassemia, 11 of deletional $\alpha^{+}$thalassemia, 19 with nondeletional $\alpha^{+}$thalassemia and 58 normal subjects by the one-way analysis of variance (ANOVA) followed by the post hoc comparisons with Scheffe's test. A level of $\mathrm{p}<0.05$ was taken as statistically significant. Comparison of the level of $\mathrm{Hb}$ Bart's in 4,000 $\mu \mathrm{g} / \mathrm{mL} \mathrm{Hb}$ solution of subjects having deletional $\mathrm{HbH}$ disease or $\mathrm{HbH}$ disease with $\mathrm{HbCS}$ with subjects having $\alpha^{0}$ thalassemia revealed higher levels with significant difference $(\mathrm{p}<0.001$ and $\mathrm{p}=0.023$, respectively). Furthermore, the level of $\mathrm{Hb}$ Bart's in subjects having $\alpha^{0}$ thalassemia was significantly higher than that for subjects having deletional $\alpha^{+}$thalassemia $(\mathrm{p}<0.001)$. Most significantly, the level of $\mathrm{Hb}$ Bart's in all types of $\alpha$ thalassemia was significantly higher than normal subjects $(p<0.0001)$.

The concentrations of Hb Bart's in hemoglobin solution of $1,000 \mu \mathrm{g} / \mathrm{mL} \mathrm{Hb}$ of the same subjects were also investigated, however, it was not the appropriate concentration for 
Table 1. Quantitative ELISA Determination of Hb Bart's in Hemoglobin Solution Containing 4,000 $\mu \mathrm{g} / \mathrm{mL} \mathrm{Hb}$ and some Hematological Features of Deletional HbH Disease $\left(--/-\alpha^{3.7}\right)$ or HbH Disease with HbCS $\left(--/ \alpha^{\text {cs }} \alpha\right)$

\begin{tabular}{|c|c|c|c|c|c|c|}
\hline $\begin{array}{l}\text { Patient } \\
\text { Number }^{*}\end{array}$ & $\begin{array}{c}\text { Concentration of Hb } \\
\text { Bart's }(\mathrm{ng} / \mathrm{mL})^{* * *}\end{array}$ & $\begin{array}{l}\text { Percent of } \\
\mathrm{HbA}_{2}{ }^{* * * * *}\end{array}$ & $\begin{array}{c}\text { PCR of } \alpha^{0} \text { Thalassemia } \\
\text { (SEA type) }\end{array}$ & $\begin{array}{l}\text { PCR of } \alpha^{+} \text {Deletion } \\
(3.7 \mathrm{~kb}) \text { Thalassemia }\end{array}$ & $\begin{array}{c}\text { PCR of } \alpha^{+} \text {Nondeletion } \\
\text { (HbCS) }\end{array}$ & Genotyping \\
\hline $\mathrm{C}-3$ & 1,425 & 1.50 & Positive & Positive & Negative & $--/-\alpha^{3.7}$ \\
\hline C-5 & 1,230 & 1.38 & Positive & Negative & Positive & $--/ \alpha^{\mathrm{CS}} \alpha$ \\
\hline $\mathrm{C}-7$ & 1,305 & 3.08 & Positive & Negative & Positive & $--/ \alpha^{\mathrm{CS}} \alpha$ \\
\hline C-11 & 1,455 & 1.24 & Positive & Positive & Negative & $--/-\alpha^{3.7}$ \\
\hline C-12 & 1,095 & 2.50 & Positive & Negative & Positive & $--/ \alpha^{\mathrm{CS}} \alpha$ \\
\hline C-13 & 1,680 & 2.10 & Positive & Negative & Positive & $--/ \alpha^{\mathrm{CS}} \alpha$ \\
\hline C-23 & 1,650 & 2.99 & Positive & Positive & Negative & $--/-\alpha^{3.7}$ \\
\hline
\end{tabular}

*Offspring with deletional or nondeletional $\mathrm{HbH}$ diseases ( $\mathrm{HbH}$ disease with $\mathrm{HbCS}$ ) (age 4-14 years).

$* *$ Mean \pm S.D. of Hb Bart's $=1,374 \pm 210 \mathrm{ng} / \mathrm{mL}$; Range $=1,164-1,584 \mathrm{ng} / \mathrm{mL}$. *** Mean \pm S.D. of $\mathrm{HbA}_{2}=2.08 \pm 0.61 \%$.

Note: $\mathrm{Hb}$ typing all are $\mathrm{AH}$; inclusion bodies in $\mathrm{RBC}=$ trace to +2 ; acid elution $=0$ to +2 .

the differentiation of $\alpha$ thalassemia from normal subjects as compared to the $4,000 \mu \mathrm{g} / \mathrm{mL} \mathrm{Hb}$ solution (data not shown). The Hb Bart's concentrations in hemoglobin solution could be calculated from a standard curve, which was generated by the same polyclonal (RPB) and monoclonal (2D4) antisera using various concentrations of standard $\mathrm{Hb}$ Bart's. The standard curve could be constructed and used for the calculation of Hb Bart's concentrations [4].

\section{DISCUSSION AND CONCLUSION}

Thalassemia is considered the most common genetic disorder worldwide with highest concentration of $\alpha$ thalassemia genes in Southeast Asia and along the west coast of Africa [3]. The resettlement of nearly two million refugees from Cambodia, Laos, and Vietnam in the 1970s and 1980s has led to increasing symptomatic $\alpha$ thalassemia syndromes in North America and Europe [17]. Although it is possible to subdivide the $\alpha$ thalassemia clinical syndromes into four categories: (1) silent carrier, (2) $\alpha$-thalassemia trait, (3) $\mathrm{HbH}$ disease, and (4) $\alpha$-thalassemic hydrops fetalis, there could be significant overlap among these groups based upon the spectrum of clinical severity within each category [1].

It has long been recognized that the presence of $\mathrm{Hb}$ Bart's in the Asian newborn is associated with $\alpha$-thalassemia; however, the exact molecular basis of the relationship has not been established [3]. It has also been found that in the newborns of black people, an elevation of $\mathrm{Hb}$ Bart's is correlated with the deletion of one or two $\alpha$-globin genes [3]. In the present study, we intended to determine the amount of $\mathrm{Hb}$ Bart's in hemolysates from children and adult subjects using a custom-developed ELISA technique. Our data showed that we were able to detect and quantify the concentration of $\mathrm{Hb}$ Bart's in $4,000 \mu \mathrm{g} / \mathrm{mL} \mathrm{Hb}$ solution for 18 subjects having deletional $\mathrm{HbH}$ disease $(1,537 \pm 339 \mathrm{ng} / \mathrm{mL}), 21$ having
$\mathrm{HbH}$ disease with $\mathrm{HbCS}(1,268 \pm 284 \mathrm{ng} / \mathrm{mL}), 33$ having $\alpha^{0}$ thalassemia $(967 \pm 438 \mathrm{ng} / \mathrm{mL}), 19$ having nondeletional $\alpha^{+}$thalassemia $(712 \pm 420 \mathrm{ng} / \mathrm{mL})$, and 11 having deletional $\alpha^{+}$thalassemia $(318 \pm 221 \mathrm{ng} / \mathrm{mL})$. In contrast, we could not detect $\mathrm{Hb}$ Bart's $(0 \mathrm{ng} / \mathrm{mL})$ in any of the 58 normal adult subjects. Our data thus show that it is possible to quantify the level of Hb Bart's in children and adult hemolysates for distinguishing $\alpha$ thalassemic subjects from normal people. It was further possible to distinguish cases of deletional $\mathrm{HbH}$ disease and $\mathrm{HbH}$ disease with $\mathrm{HbCS}$ from $\alpha^{0}$ - and $\alpha^{+}$-thalassemias by the level of Hb Bart's in the hemolysate. Furthermore, the subjects having $\alpha^{0}$ thalassemia exhibited a significantly higher level of $\mathrm{Hb}$ Bart's than those having deletional $\alpha^{+}$thalassemia $(p<0.001)$. In this study, all 11 deletional $\alpha^{+}$thalassemia were the $3.7 \mathrm{~kb}$ deletion type while the $4.2 \mathrm{~kb}$ deletion could not be detected because the $3.7 \mathrm{~kb}$ deletion being more common in Thai population [18].

It has been reported that in many but not all infants who are heterozygous for deletional forms of $\alpha^{+}$thalassemia $(-\alpha / \alpha \alpha)$, it is possible to detect small amounts of Hb Bart's in their cord blood, while the homozygous $\alpha^{+}$thalassemia $(-\alpha /-\alpha)$ individuals exhibit approximately $5-10 \%$ concentration levels of $\mathrm{Hb}$ Bart's at birth. In both cases, the Hb Bart's disappears during the first few months of life and is not replaced by a similar amount of $\mathrm{HbH}[3,19]$. However, from our study, we were able to quantify Hb Bart's in the blood of all adults having deletional $\left(-\alpha^{3.7} / \alpha \alpha\right)$ or nondeletional $\left(\alpha \alpha / \alpha^{\mathrm{cs}} \alpha\right) \alpha^{+}$thalassemia, $\alpha^{0}$ thalassemia, deletional $\mathrm{HbH}$ disease, or $\mathrm{HbH}$ disease with $\mathrm{HbCS}$. The reason we were able to detect and quantify the amount of $\mathrm{Hb}$ Bart's both in children and adults having various types of $\alpha$ thalassemias in this study is likely due to the more sensitive detection capability of our ELISA compared to hemoglobin electrophoresis. 
Table 2. Quantitative ELISA Determination of Hb Bart's in Adult Hemoglobin Solution Containing 4,000 $\mu \mathrm{g} / \mathrm{mL} \mathrm{Hb}$ and some Hematological Features of $\alpha^{0}$ Thalassemia (--/ $\left.\alpha \alpha\right)$

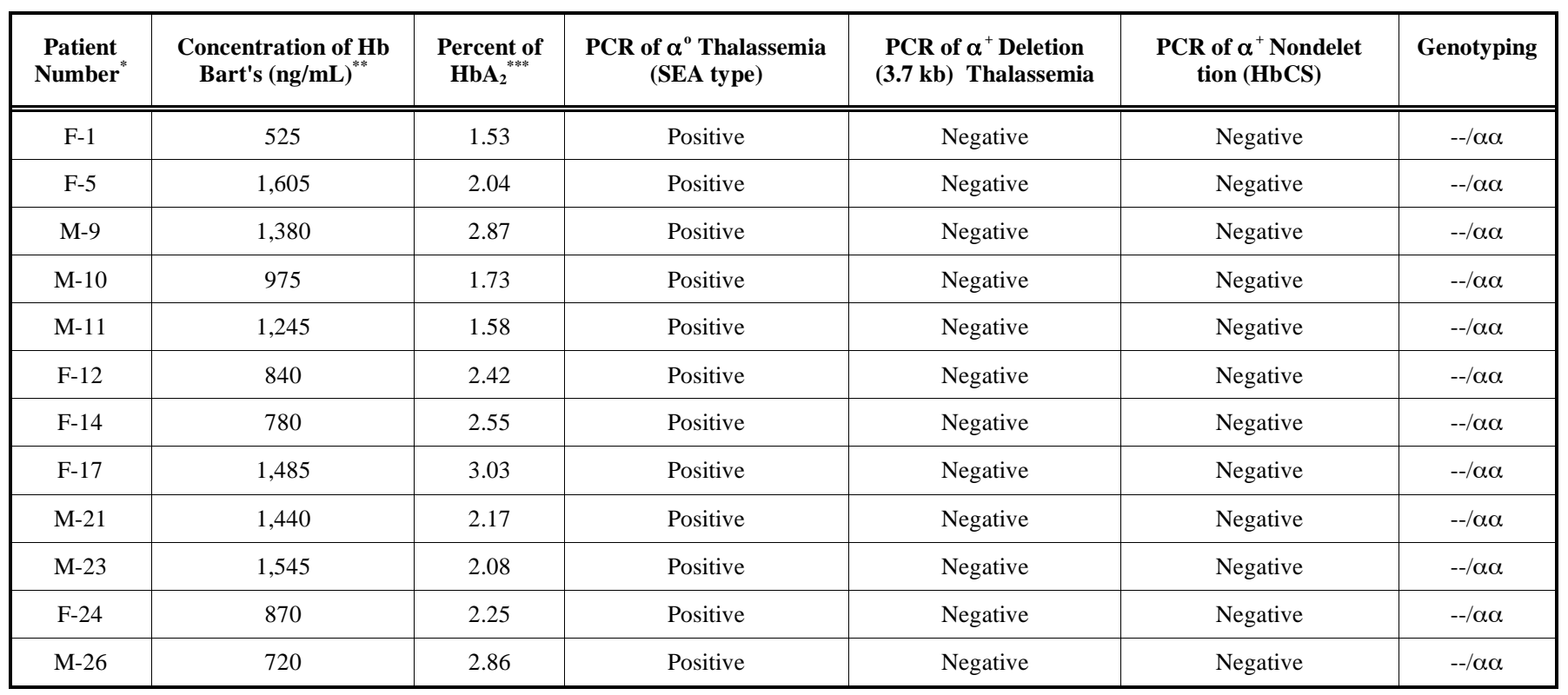

*Fathers (F) or mothers (M) of $\mathrm{HbH}$ diseases, who are $\alpha^{\circ}$ thalassemia; the numbers of $\mathrm{F}$ or $\mathrm{M}$ indicate they are father or mother of the HbH disease patients having the same number in Table 1.

**Mean \pm S.D. of Hb Bart's $=1,118 \pm 357 \mathrm{ng} / \mathrm{mL} ;$ Range $=761-1,475 \mathrm{ng} / \mathrm{mL}$. *** Mean \pm S.D. of $\mathrm{HbA}_{2}=2.26 \pm 0.50 \%$.

Note: $\mathrm{Hb}$ typing all are $\mathrm{AA}$; inclusion bodies in $\mathrm{RBC}=0$; acid elusion $=0$.

Table 3. Quantitative ELISA Determination of Hb Bart's in Adult Hemoglobin Solution Containing 4,000 $\mu \mathrm{g} / \mathrm{mL} \mathrm{Hb}$ and some Hematological Features of Deletional $\left(-\alpha^{3.7} / \alpha \alpha\right)$ or Nondeletional $\left(\alpha \alpha / \alpha^{\mathrm{cs}} \alpha\right) \alpha^{+}$Thalassemia and Normal Subjects $(\alpha \alpha / \alpha \alpha)$

\begin{tabular}{|c|c|c|c|c|c|c|}
\hline $\begin{array}{l}\text { Patient } \\
\text { Number }^{*}\end{array}$ & $\begin{array}{l}\text { Concentration of Hb } \\
\text { Bart's }(\mathbf{n g} / \mathbf{m L})^{* * *}\end{array}$ & $\begin{array}{l}\text { Percent of } \\
\mathbf{H b A}_{2}^{* * * *}\end{array}$ & $\begin{array}{c}\text { PCR of } \alpha^{0} \text { Thalassemia } \\
\text { (SEA type) }\end{array}$ & $\begin{array}{l}\text { PCR of } \alpha^{+} \text {Deletion } \\
(3.7 \mathrm{~kb}) \text { Thalassemia }\end{array}$ & $\begin{array}{l}\text { PCR of } \alpha^{+} \text {Nondelet } \\
\text { tion (HbCS) }\end{array}$ & Genotyping \\
\hline F-10 & 465 & 2.00 & Negative & Negative & Positive & $\alpha \alpha / \alpha^{\mathrm{CS}} \alpha$ \\
\hline F-11 & 400 & 1.88 & Negative & Positive & Negative & $-\alpha^{3.7} / \alpha \alpha$ \\
\hline M-12 & 320 & 2.50 & Negative & Negative & Positive & $\alpha \alpha / \alpha^{\mathrm{CS}} \alpha$ \\
\hline M-14 & 280 & 2.45 & Negative & Negative & Positive & $\alpha \alpha / \alpha^{\mathrm{CS}} \alpha$ \\
\hline M-17 & 290 & 3.55 & Negative & Positive & Negative & $-\alpha^{3.7} / \alpha \alpha$ \\
\hline $\mathrm{F}-22$ & 525 & 2.27 & Negative & Positive & Negative & $-\alpha^{3.7} / \alpha \alpha$ \\
\hline F-23 & 150 & 2.04 & Negative & Positive & Negative & $-\alpha^{3.7} / \alpha \alpha$ \\
\hline M-24 & 705 & 2.16 & Negative & Negative & Positive & $\alpha \alpha / \alpha^{\mathrm{CS}} \alpha$ \\
\hline F-37 & 175 & 2.73 & Negative & Positive & Negative & $-\alpha^{3.7} / \alpha \alpha$ \\
\hline $\begin{array}{l}\text { Normal } \\
\text { subjects }\end{array}$ & 0 & $2.67 \pm 0.45$ & Negative & Negative & Negative & $\alpha \alpha / \alpha \alpha$ \\
\hline 12 samples & (all) & $($ mean $\pm S D)$ & (all) & (all) & (all) & (all) \\
\hline
\end{tabular}

*Fathers $(\mathrm{F})$ or mothers $(\mathrm{M})$ of $\mathrm{HbH}$ diseases, who are deletional or nondeletional $\alpha^{+}$thalassemia; the numbers of $\mathrm{F}$ or $\mathrm{M}$ indicate they are father or mother of the $\mathrm{HbH}$ diseases patients having the same number in Table 1 .

$* *$ Mean \pm S.D. of Hb Bart's $=451 \pm 230 \mathrm{ng} / \mathrm{mL} ;$ Range $=221-681 \mathrm{ng} / \mathrm{mL}$

$* * *$ Mean \pm S.D. of $\mathrm{HbA}_{2}=2.41 \pm 0.44 \%$

Note: $\mathrm{Hb}$ typing all are $\mathrm{AA}$; inclusion bodies in $\mathrm{RBC}=0$; acid elution $=0$ to trace in $\alpha^{+}$thalassemia.

$\mathrm{Hb}$ typing all are $\mathrm{AA}$; inclusion bodies in $\mathrm{RBC}=0$; acid elution $=0$ in normal subjects. 
A

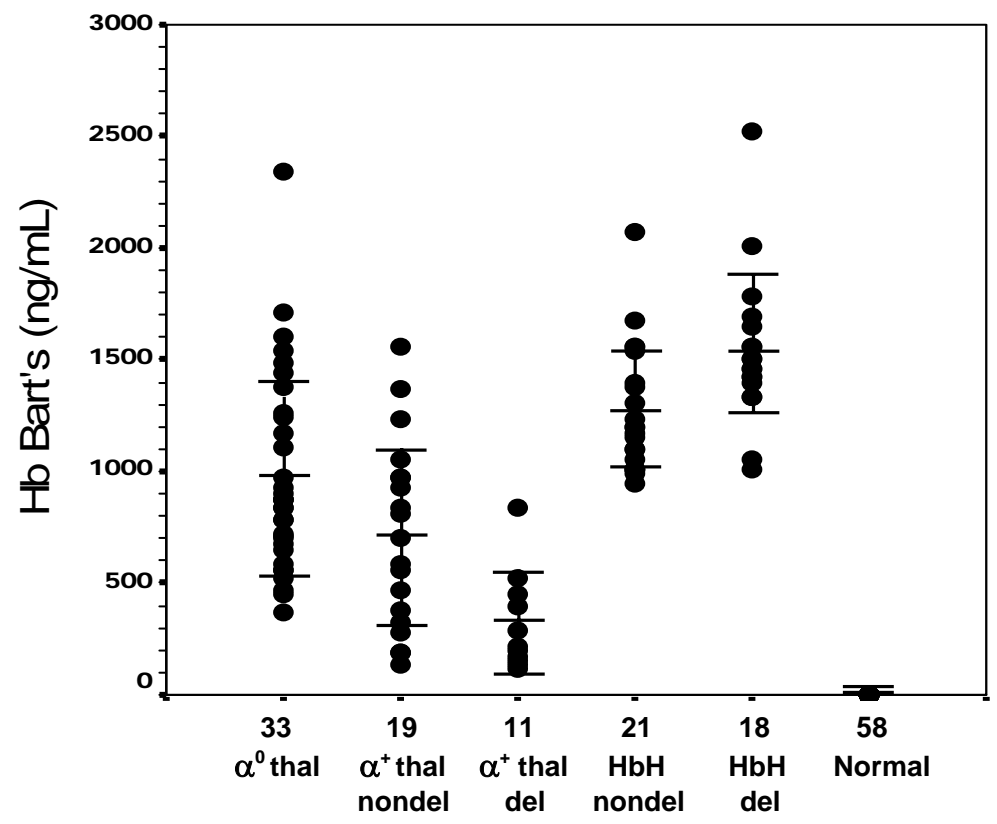

B

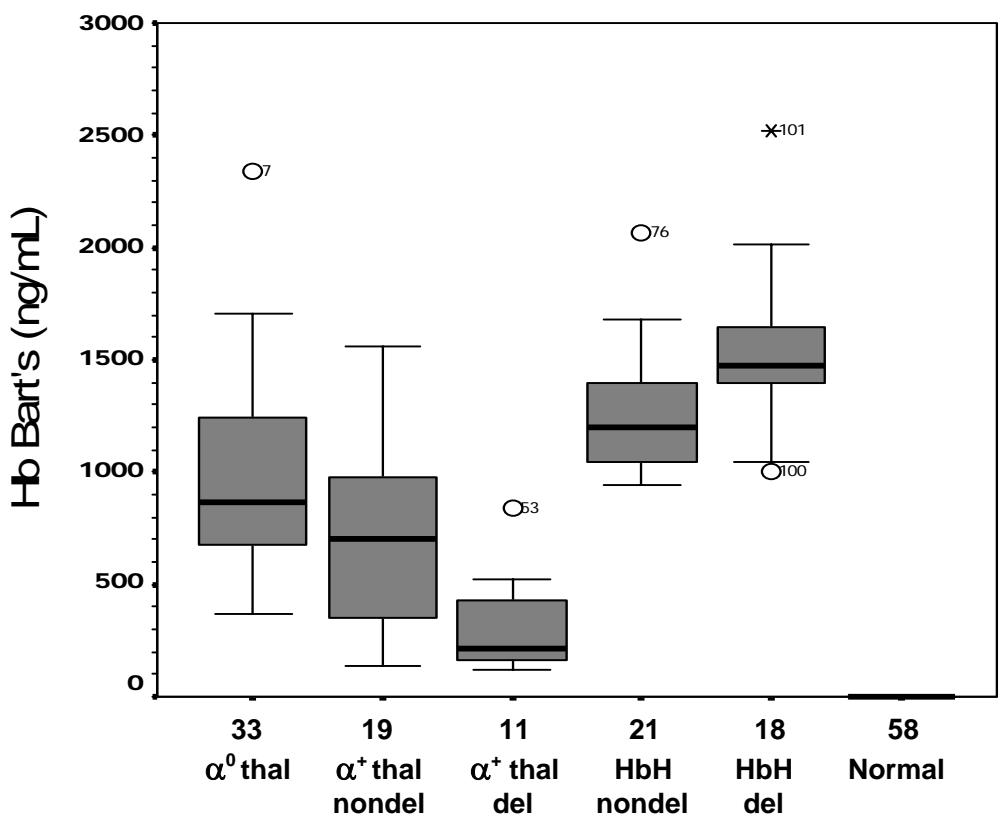

Fig. (1). Quantitative ELISA determination of Hb Bart's in hemoglobin solution containing 4,000 $\mu \mathrm{g} / \mathrm{mL} \mathrm{Hb}$ from children or adults with various types of $\alpha$ thalassemia and normal subjects. All subjects were shown in scatter diagram with mean and S.D. (A) and in post hoc comparisons by Scheffe's test with median and 25-75\% quartiles of $\mathrm{Hb}$ Bart's level (B).

It is known that for adults having $\alpha^{0}$ thalassemia, there are no changes in the hemoglobin pattern, but at birth, there is $5-10 \%$ concentration level of Hb Bart's [3]. For $\alpha^{+}$ thalassemia, some newborn infants exhibit a slight elevation of Hb Bart's (1-2\%). However, this is not always the case, and it is not always possible to identify this condition with certainty in the neonatal period, or at any other time, other than by DNA analysis [3]. From our findings, however, we were able to distinguish both $\alpha^{0}$ and $\alpha^{+}$thalassemia (both deletional and nondeletional) from normal subjects using the level of Hb Bart's in their hemolysates, even in their adult lives. We are able to show that Hb Bart's can be detected and quantified from hemoglobin solution of subjects having various types of $\alpha$ thalassemia, while it cannot be detected in hemoglobin solution containing $4,000 \mu \mathrm{g} / \mathrm{mL} \mathrm{Hb}$ of normal adult blood. We, therefore, tried to detect and quantify the level of $\mathrm{Hb}$ Bart's in hemoglobin solution containing 100, $1,000,4,000,8,000,16,000$, and $32,000 \mu \mathrm{g} / \mathrm{mL} \mathrm{Hb}$ of the 58 normal adult blood. However, we were unable to detect any $\mathrm{Hb}$ Bart's in any concentrations of the hemoglobin solution 
from the normal adult blood (data not shown). We thus conclude that our developed ELISA method can be used to detect or quantify $\mathrm{Hb}$ Bart's levels for distinguishing normal adult subjects from those having $\alpha$ thalassemias. Furthermore, the level of $\mathrm{Hb}$ Bart's in subjects having deletional $\alpha^{+}$thalassemia was significantly lower than that for subjects having $\alpha^{0}$ thalassemia, and the level of $\mathrm{Hb}$ Bart's in subjects having $\alpha^{0}$ thalassemia was significantly lower than that for subjects having deletional $\mathrm{HbH}$ disease or $\mathrm{HbH}$ disease with HbCS. All of our results suggested that the ELISA assay could be used as a screening test for the determination of $\alpha$ thalassemia carriers in general population.

\section{ACKNOWLEDGMENTS}

This research was supported by the National Center for Genetic Engineering and Biotechnology, National Science and Technology Development Agency, Thailand. We thank Professor Dr. Robert W. Gracy of the University of North Texas, USA for revising our manuscript. We appreciate the statistical analysis of our data by Associate Professor Teraporn Vutyavanich and Ms Rung-aroon Sreshthaputra of Chiang Mai University.

\section{REFERENCES}

[1] Weatherall DJ. The thalassemias. In: Stamatoyannopoulos G, Majerus PW, Perlmutter RM, Varmus H, Eds. The Molecular Basis of Blood Diseases. $3^{\text {rd }}$ ed. Philadelphia, Pa, WB, Saunders Co. 2001; pp. 183-226.

[2] Lukens JN. The thalassemias and related disorders: quantitative disorders of hemoglobin synthesis. In: Lee GR, Foerster J, Lukens J, Paraskevas F, Greer JP, Rodgers GM, Ed. Wintrobe's Clinical Hematology. $10^{\text {th }}$ ed. Baltimore, Md, Williams \& Wilkins 1999; vol. 1: pp. 1405-1448.

[3] Weatherall DJ, Clegg JB. The Thalassaemia Syndromes. $4^{\text {th }}$ ed. Oxford, England: Blackwell Science Ltd 2001.

[4] Makonkawkeyoon L, Pharephan S, Makonkawkeyoon S. Production of a mouse hybridoma secreting monoclonal antibody highly specific to hemoglobin Bart's $\left(\gamma_{4}\right)$. Lab Hematol 2006; 12: 193-200.
[5] Miller SA, Dykes DD, Polesky HF. A simple salting out procedure for extracting DNA from human nucleated cells. Nucleic Acids Res 1988; 16: 1215.

[6] Old J, Traeger-Synodios J, Galnello R, Petrou M, Angastiniotis M. Prevention of Thalassemias and Other Haemoglobin Disorders. Laboratory Methods. Nicosia, Cyprus:Team up Creations Ltd; 2005; vol. 2.

[7] Hay FC, Westwood OMR. Practical Immunology. $4^{\text {th }}$ ed. Oxford, England: Blackwell Science Ltd 2002.

[8] Bradford MM. A rapid and sensitive method for the quantitation of microgram quantities of protein utilizing the principle of protein-dye binding. Anal Biochem 1976; 72: 248-54.

[9] Goding JW. Monoclonal Antibodies: principles and Practice. $2^{\text {nd }}$ ed. London, England: Academic Press Inc 1986.

[10] Crowther JR. The ELISA Guidebook: methods in Molecular Biology. Totawa, NJ: Humana Press Inc 2001; vol. 149.

[11] Brown BA. Hematology: Principles and Procedures. $5^{\text {th }}$ ed Philadelphia, Pa: Lea \& Febiger 1988.

[12] Huisman TH, Schroeder WA, Brodie AN, Mayson SM, Jakway J. Microchromatography of hemoglobins. II. A simplified procedure for the determination of hemoglobin $\mathrm{A}_{2}$. J Lab Clin Med 1975; 86: 700-2.

[13] Bowden DK, Vickers MA, Higgs DR. A PCR-based strategy to detect the common severe determinants of $\alpha$-thalassemia. $\mathrm{Br} \mathrm{J}$ Haematol 1992; 81: 104-8.

[14] Smetanina NS, Huisman TH. Detection of $\alpha$-thalassemia2 $(-3.7 \mathrm{~kb})$ and its corresponding triplication $\alpha \alpha \alpha$ (anti-3.7kb) by PCR: an improved technical change. Am J Hematol 1996; 53: 202-3.

[15] Baysal E, Huisman TH. Detection of common deletional $\alpha$-thalassemia-2 determinants by PCR. Am J Hematol 1994; 46: 208-13.

[16] Makonkawkeyoon L, Sanguansermsri T, Asato T, Nakashima Y, Takei H. Rapid detection of chain termination mutations in the $\alpha-2$ globin gene. Blood 1993; 82: 3503-4.

[17] Anderson HM, Ranney HM. Southeast Asian Immigrants: the new thalassemias in Americans. Semin Hematol 1990; 27: 239-46.

[18] Winichagoon P, Higgs DR, Goodbourn SEY, Clegg JB, Weatherall DJ, Wasi P. The molecular basis of $\alpha$-thalassemia in Thailand. EMBO J 1984; 3: 1813-8.

[19] Higgs DR, Vickers MA, Wilkie AO, Pretorius IM, Jarman AP, Weatherall DJ. A review of the molecular genetics of the human $\alpha$-globin gene cluster. Blood 1989; 73: 1081-104. 